\title{
Slum Upgrading and Health Equity
}

\author{
Jason Corburn * and Alice Sverdlik \\ Department of City and Regional Planning \& School of Public Health, University of California, Berkeley, \\ CA 94720, USA; sverdlik@berkeley.edu \\ * Correspondence: jcorburn@berkeley.edu; Tel.: +1-510-643-4790
}

Academic Editor: Paul B. Tchounwou

Received: 14 November 2016; Accepted: 17 March 2017; Published: 24 March 2017

\begin{abstract}
Informal settlement upgrading is widely recognized for enhancing shelter and promoting economic development, yet its potential to improve health equity is usually overlooked. Almost one in seven people on the planet are expected to reside in urban informal settlements, or slums, by 2030. Slum upgrading is the process of delivering place-based environmental and social improvements to the urban poor, including land tenure, housing, infrastructure, employment, health services and political and social inclusion. The processes and products of slum upgrading can address multiple environmental determinants of health. This paper reviewed urban slum upgrading evaluations from cities across Asia, Africa and Latin America and found that few captured the multiple health benefits of upgrading. With the Sustainable Development Goals (SDGs) focused on improving well-being for billions of city-dwellers, slum upgrading should be viewed as a key strategy to promote health, equitable development and reduce climate change vulnerabilities. We conclude with suggestions for how slum upgrading might more explicitly capture its health benefits, such as through the use of health impact assessment (HIA) and adopting an urban health in all policies (HiAP) framework. Urban slum upgrading must be more explicitly designed, implemented and evaluated to capture its multiple global environmental health benefits.
\end{abstract}

Keywords: slums; health equity; slum upgrading; social determinants of health; climate change adaptation; housing; participation; sustainable development goals; health in all policies

\section{Introduction}

Few urban initiatives have greater potential to promote health equity and to advance the well-being of poor households in the Global South than participatory, multi-objective slum upgrading. Urban informal settlements are communities that are highly diverse and have a range of locally-specific names (such as barrios, bustees, mjondolo, or favelas). Here we use the terms "slums" and "informal settlements" to denote largely self-built urban communities, which are rarely recognized officially and typically are denied life-supporting services and infrastructure. Not only can upgrading these settlements improve health outcomes via enhanced access to shelter, water, or clean energy, but it can also advance the 2030 Agenda for Sustainable Development. The 2030 Agenda has established 17 interrelated Sustainable Development Goals (SDGs), which will require implementing multi-sectoral strategies to support health and well-being and include explicit reference to slum upgrading. Yet, as we will highlight, upgrading projects are rarely designed to explicitly improve nor are they evaluated for how well they have positively shaped the social determinants of slum health.

The social determinants of health $(\mathrm{SDOH})$ are factors outside medical care that shape health outcomes, such as safe housing, food access, political and gender rights, education and employment status [1]. In urban informal settlements, residents are often burdened with multiple and overlapping challenges that can undermine the $\mathrm{SDOH}$, from entrenched poverty, to overcrowded shelter, to inadequate infrastructure and tenure insecurity, all of which can combine to contribute to increased 
risk of exposures to environmental pathogens that increase infectious and non-communicable diseases in urban poor areas [2,3]. Slum-dwellers also experience spatial, political, and economic exclusion when compared to wealthier urban residents, and these too are recognized as powerful determinants of who gets sick, suffers more and dies early [4].

In this review article, we analyzed slum upgrading projects and published evaluations of these projects or policies for whether and how they captured the influence of upgrading on the SDOH [5]. We analyzed completed slum upgrading projects from a dozen different countries and performed content analyses to determine if these projects included explicit measures of any SDOH and/or specific disease outcomes. We focused our review on upgrading projects and policies that took an "integrated" (i.e., multi-sectoral) approach to upgrading since we determined that these aimed to influence the $\mathrm{SDOH}$ through interventions focused on more than one physical, social and/or political issue facing the urban poor [6,7]. We also limited our review to slum upgrading interventions where we could identify at least two published evaluation reports. By incorporating a wide range of peer-reviewed and grey literature, we aimed to distinguish our study from past research that only reviewed the health outcomes, but not necessarily the broad determinants, of slum upgrading projects utilizing randomized studies [8]. As discussed in more detail below, we found that a majority of slum upgrading projects rarely measured how upgrading projects affected health outcomes or social determinants. We suggest that this represents a lost opportunity for health promotion and conclude with some suggestions for how slum upgrading might more explicitly promote the $\mathrm{SDOH}$ amongst the urban poor in the Global South [9].

\section{Defining Slums, Upgrading, and Their Relationships to Health Equity}

Slum-dwellers increasingly face a "triple threat" of infectious diseases, non-communicable conditions (e.g., diabetes, cardiovascular disease, and mental illness), and injuries due to violence or road traffic accidents. Table 1 offers some definitional characteristics of slums and associated environmental health issues. However, there is no single adequate definition of slums, since they are often heterogeneous in terms of housing types, poverty prevalence, tenure (in)security, levels of infrastructure and service provision, environmental hazards and health risks [10].

Similarly, there is no single definition of "slum upgrading", as projects and policies differ based on region of the world, political and development histories, and other factors [11]. Beginning in 1972, the World Bank launched urban upgrading projects to improve services, infrastructure and housing in hopes of reducing poverty and meeting basic needs [12]. Yet governments often persisted in slum clearance and neglected to maintain what little infrastructure had been upgraded. By the 1980s-1990s, international development agencies shifted their approach to slum upgrading; rather than construct housing and infrastructure, governments acted as "enablers" by offering financing for mostly non-governmental organizations' projects, which largely focused on housing [13]. By the early 2000s another shift occurred and a greater emphasis was placed on in-situ upgrading, limiting slum clearance and launching policies that aimed to integrate the urban poor into the larger fabric of growing metropolitan economies [6,13].

As used here, "slum upgrading" denotes initiatives seeking to improve housing quality, infrastructure provision, social services, livelihoods, and official recognition for residents. Slum upgrading is also a process that meaningfully includes the urban poor in project and policy design and implementation, aims to integrate slums into the larger fabric of the city, is attentive to emerging challenges of climate change adaptation, and is often incremental-meaning that residents remain in place while improvements occur to prevent displacement (cf.: http:/ / www.citiesalliance. org/About-slum-upgrading\#Why_is_slum_upgrading_important). Yet, the scope of upgrading can vary from small-scale sector-specific projects (i.e., water-taps, paved roads, street lighting) to comprehensive housing and infrastructure projects (i.e., piped water and sewers into improved housing) to integrated projects that combine built-environment interventions with social programs and political empowerment $[13,14]$. Many upgrading programs have also focused on providing 
residents with legal rights to land and housing tenure [15]. Importantly, slum upgrading requires state recognition of the urban poor, their settlements, and the need to deliver basic services. By granting official legitimacy to slum-dwellers and their "right to remain", upgrading represents an important alternative to slum removal and may be a process that in itself may offer health benefits [8]. However, as we explore below, upgrading projects are rarely evaluated on their ability to positively influence the social determinants of health.

Table 1. Slum definitions and select health risks.

\begin{tabular}{|c|c|c|}
\hline Example Slum Characteristics & Definition and Indicators (Examples) & Community Health Risks (Select) \\
\hline Overcrowding & $>2$ persons/room or $<5 \mathrm{~m}^{2}$ per person & $\begin{array}{l}\text { Spread of TB, influenza, meningitis, skin infections } \\
\text { and rheumatic heart disease [16]. }\end{array}$ \\
\hline Low-Quality Housing Structure & $\begin{array}{l}\text { Inferior building materials dirt floors \& } \\
\text { substandard construction }\end{array}$ & $\begin{array}{l}\text { Vulnerability to floods, extreme heat/cold, burns and } \\
\text { falling injuries [17]. }\end{array}$ \\
\hline Hazardous Housing Sites & $\begin{array}{l}\text { Geological and site hazards (e.g., } \\
\text { industrial waste sites, garbage dumps, } \\
\text { railways, wetlands, steep slopes, etc.) }\end{array}$ & $\begin{array}{l}\text { Acute poisoning; unintentional injuries, landslides, } \\
\text { flooding, toxic contamination, environmental } \\
\text { pollutants, leptospirosis, cholera, malaria, dengue, } \\
\text { hepatitis, drowning [18]. }\end{array}$ \\
\hline Inadequate Water Access & $\begin{array}{l}<50 \% \text { of households have affordable, } 24 / 7 \\
\text { access to piped water/public standpipe }\end{array}$ & $\begin{array}{l}\text { Malaria, dengue and diarrheal diseases, cholera, } \\
\text { typhoid, hepatitis; increased HIV/AIDS } \\
\text { vulnerability [19]. }\end{array}$ \\
\hline Inadequate Sanitation Access & $\begin{array}{l}<50 \% \text { of households with sewer, septic } \\
\text { tank, pour-flush or ventilated } \\
\text { improved latrine }\end{array}$ & $\begin{array}{l}\text { Fecal-oral diseases, hookworms, roundworm; missed } \\
\text { school-days during girls' menstruation; malnutrition } \\
\text { and children's stunting; safety/sexual violence for } \\
\text { women from unsafe toilets [20]. }\end{array}$ \\
\hline Limited Services and Infrastructure & $\begin{array}{l}\text { Inadequate healthcare, drainage, roads, } \\
\text { energy, transport, schools, and/or } \\
\text { refuse collection }\end{array}$ & $\begin{array}{l}\text { Traffic injuries; lack emergency provision; fires; } \\
\text { flooding/drowning; waste burning and air pollution; } \\
\text { respiratory diseases and cancer [21]. }\end{array}$ \\
\hline Tenure Insecurity & $\begin{array}{l}\text { Lack of formal title deeds to land } \\
\text { and/or structure }\end{array}$ & $\begin{array}{l}\text { Fear; increased hypertension; diabetes; low birth } \\
\text { weight newborns [22]. }\end{array}$ \\
\hline Poverty and Informal Livelihoods & $\begin{array}{l}\text { Low incomes, few assets, and access to } \\
\text { credit; lack of social protection }\end{array}$ & $\begin{array}{l}\text { Increased occupational hazards; maternal health } \\
\text { complications; vaccine-preventable diseases [23]; } \\
\text { perinatal diseases; drug-resistant infections; }\end{array}$ \\
\hline Violence and Insecurity & $\begin{array}{l}\text { Elevated crime, including domestic and } \\
\text { gender-based violence }\end{array}$ & $\begin{array}{l}\text { Homicides; hypertension; obesity; sexual violence; } \\
\text { vulnerability to STIs, esp for young people forced } \\
\text { into sex work [24]. }\end{array}$ \\
\hline Political Disempowerment & $\begin{array}{l}\text { Low or no governmental responsiveness } \\
\text { to needs and services }\end{array}$ & $\begin{array}{l}\text { Lack of health services; poor education; preventable } \\
\text { hospitalizations; typhus, leptospirosis, cholera, } \\
\text { chronic respiratory diseases, growth retardation [25]. }\end{array}$ \\
\hline
\end{tabular}

\section{Methods: Review of Urban Slum Upgrading Projects}

Our analysis of slum upgrading evaluations incorporated both grey literature and published peer-reviewed studies, with a focus on integrated interventions. We started with a scan of published literature between 1997 and 2016 through on-line databases using general search terms, including "informal settlement", "slum", "upgrading" and "health". Based on this review, we found 182 possible evaluations but narrowed them down to thirty-two by selecting those that had at least one additional published report on the project. We also narrowed our search by focusing upon "integrated" or multi-sectoral interventions, which aimed to address physical, social and urban governance concerns in informal settlements [26,27]. We focused our search on multi-sectoral interventions because we hypothesized that these might offer reviews and/or evaluations of several environmental and social impacts. Further, global slum upgrading programs, such as UN-Habitat's Participatory Slum Upgrading Program, call for integrated or "blended" projects that aim to achieve multiple objectives [28]. We also limited our search to find projects that might act as examples of the type of cross-sector interventions called for under the Sustainable Development Goals [29]. We utilized the WHO definition of SDOH to sharpen our search terms and refined our findings into three categories under which upgrading initiatives may influence health in informal settlements: national and municipal policies, structural determinants, and living and work conditions [1,9]. By "national and municipal policies", we mean any legislation or government-sponsored initiatives that may positively influence the $\mathrm{SDOH}$, including a slum upgrading policy or financing scheme. This category thus underscores that governmental 
decisions and priorities-often outside the medical and public health sectors-are key drivers of population health. By "structural determinants", we focus on the specific population drivers of health inequities frequently identified in the $\mathrm{SDOH}$ literature, including income and wealth, educational access, employment, early childhood development, food security, and social exclusion. By "living and working conditions", we focus on the physical characteristics of neighborhoods and urban places, such as access to quality and affordable housing, water, sanitation, electricity, transport, etc.

We selected nineteen interventions from Latin American, African and Asian cities that met our screening criteria; while not exhaustive, this list is meant to illustrate the range of slum upgrading projects globally and the potential of participatory, integrated projects for improving human health. We summarize select characteristics of each slum upgrading project and whether and how they were evaluated for impacts on human health in Table 2.

Table 2. Integrated slum upgrading programs and measured health impacts.

\begin{tabular}{|c|c|c|}
\hline Project Name and Location (Reference) & Focus of Upgrading & $\begin{array}{l}\text { Health and Well-Being Impacts } \\
\text { (If Measured) }\end{array}$ \\
\hline $\begin{array}{l}\text { Visakhaptnam, Indore and Vijaywada } \\
\text { Upgrading, India }[30,31]\end{array}$ & $\begin{array}{l}\text { Roads, water, lighting, social services } \\
\text { and micro-loans }\end{array}$ & $\begin{array}{l}\text { Safety and reduced women's } \\
\text { time burdens }\end{array}$ \\
\hline $\begin{array}{l}\text { Slum Networking Project (SNP), } \\
\text { Ahmedabad, India [32-34] }\end{array}$ & $\begin{array}{l}\text { Infrastructure, governance, } \\
\text { electrification }\end{array}$ & Reduction in water-borne illness \\
\hline $\begin{array}{l}\text { SPARC, the National Slum Dwellers } \\
\text { Federation and Mahila Milan, Mumbai and } \\
\text { Pune, India }[35,36]\end{array}$ & $\begin{array}{l}\text { Water and sanitation, toilets, } \\
\text { community governance }\end{array}$ & None explicitly measured \\
\hline Baan Mankong, Bangkok, Thailand $[37,38]$ & $\begin{array}{l}\text { Housing, tenure, infrastructure, } \\
\text { daycare, services for elderly }\end{array}$ & None explicitly measured \\
\hline $\begin{array}{l}\text { Kampong Improvement Project (KIP), } \\
\text { Indonesia }[39,40]\end{array}$ & $\begin{array}{l}\text { Piped water, housing improvements, } \\
\text { flood risk reduction }\end{array}$ & None explicitly measured \\
\hline $\begin{array}{l}\text { Zonal Improvement Program (ZIP), } \\
\text { Manila, Philippines }[41,42]\end{array}$ & $\begin{array}{l}\text { Water, roads, housing, land rights, } \\
\text { electricity }\end{array}$ & Reduced incidence diarrhea \\
\hline $\begin{array}{l}\text { Neighborhood Upgrading and Shelter, } \\
\text { Indonesia }[43,44]\end{array}$ & $\begin{array}{l}\text { Roads, streetlights, water, toilets, solid } \\
\text { waste management }\end{array}$ & Avoided health costs \\
\hline $\begin{array}{l}\text { Karachi, Orangi Pilot Project (OPP), } \\
\text { Karachi, Pakistan }[45,46]\end{array}$ & Water, sanitation, capacity-building & Reduced Infant Mortality \\
\hline PRIMED, Medellín, Colombia $[47,48]$ & $\begin{array}{l}\text { Housing tenure, } \\
\text { physical infrastructure }\end{array}$ & Improved safety perceptions \\
\hline Favela Bairro, Rio de Janeiro, Brazil $[49,50]$ & $\begin{array}{l}\text { Infrastructure, housing, } \\
\text { social programs }\end{array}$ & $\begin{array}{l}\text { Mortality from parasitic or viral } \\
\text { vector-born infections; infant } \\
\text { mortality; homicides }\end{array}$ \\
\hline Bairro Legal, Sao Paulo, Brazil $[51,52]$ & $\begin{array}{l}\text { Infrastructure, housing, social and } \\
\text { economic development }\end{array}$ & Improved flood control \\
\hline $\begin{array}{l}\text { Ribeira Azul and Technical and Social } \\
\text { Support Project, Salvador, Brazil }[53,54]\end{array}$ & $\begin{array}{l}\text { Infrastructure, housing, } \\
\text { social programs }\end{array}$ & Self-reported reduction crime \\
\hline Mexico, Piso Firme $[55,56]$ & Cement floors in housing & $\begin{array}{l}\text { Children's parasitic infestations, } \\
\text { diarrhea and anemia }\end{array}$ \\
\hline PRODEL, Nicaragua $[57,58]$ & $\begin{array}{l}\text { Housing, infrastructure, microloans, } \\
\text { community savings }\end{array}$ & None explicitly measured \\
\hline $\begin{array}{l}\text { Citizen Security in Cali, Bogotá, and } \\
\text { Medellín, Colombia }[59,60]\end{array}$ & Social programs, violence prevention & $\begin{array}{l}\text { Homicide and } \\
\text { inter-personal violence }\end{array}$ \\
\hline $\begin{array}{l}\text { Huruma Community-Led Upgrading, } \\
\text { Nairobi, Kenya }[61,62]\end{array}$ & $\begin{array}{l}\text { Infrastructure, housing, } \\
\text { community savings }\end{array}$ & None explicitly measured \\
\hline $\begin{array}{l}\text { Imizamo Yethu Upgrading, Cape Town, } \\
\text { South Africa }[63,64]\end{array}$ & $\begin{array}{l}\text { Housing, water and sanitation } \\
\text { infrastructure }\end{array}$ & None explicitly measured \\
\hline $\begin{array}{l}\text { Hanna Nassif Upgrading, Dar es Salaam, } \\
\text { Tanzania }[27,65]\end{array}$ & $\begin{array}{l}\text { Infrastructure, employment, } \\
\text { tenure, transport }\end{array}$ & $\begin{array}{l}\text { Reduced waterborne } \\
\text { diseases (unspecified) }\end{array}$ \\
\hline $\begin{array}{l}\text { Kenya Slum Upgrading Program } \\
\text { (KENSUP) [66-68] }\end{array}$ & Housing, governance & None specified \\
\hline
\end{tabular}




\section{Findings: Slum Upgrading Projects and the Determinants of Health}

Of our nineteen selected projects, thirteen evaluations directly discussed potential SDOH, such as reduced water collection times; enhanced community pride and social cohesion; greater levels of micro-savings, loans, or economic stability; and increased women's empowerment. Community participation - residents' and/or community-based organizations' involvement in the project-was present in all but four of the upgrading evaluations we reviewed. However, these issues were rarely discussed as having potential benefits for population health. Eleven of the reviewed projects explicitly mentioned health impacts, using self-reported data or state collected data such as cause of death. Only three slum upgrading projects were evaluated for their influence on specific disease outcomes. In sum, our scan revealed the following:

- Health outcome measures were very limited and tended to focus on childhood mortality or morbidity (particularly due to diarrheal or other communicable illnesses);

- Economic impacts were frequently evaluated, but few studies discussed how poverty and/or income influenced the health status of slum-dwellers;

- Infrastructure improvements were measured through such variables as the number of new water-points, sanitary infrastructure or unit costs, but rarely analyzed how infrastructure might positively influence social or economic opportunities, safety, or reduce gender inequities;

- Resident participation, including through micro-savings, was frequently mentioned, but none of the reports attempted to link participation to potential positive or adverse human health impacts, the latter being social stigma and hypertension [69]; and,

- There was no consistent time frame for when evaluations took place and this varied from immediately after a project was completed to, on average, 18 months after completion.

\subsection{National/Municipal Policies for the Urban Poor}

We found that slum upgrading projects are typically place-specific, but more rarely part of ongoing national or municipal policy priorities. However, at least one-third of the projects included in this review had established national and/or municipal policies to support slum upgrading, including in Brazil, Colombia, Mexico, Nicaragua, India, Thailand and Kenya. In Thailand, the Baan Mankong program is supported by the Community Organization Development Institute (CODI), a national governmental agency that provides housing loans, infrastructure subsidies, and ongoing support to cities and communities to collaborate in slum upgrading projects [15]. Favela Bairro, an intervention of the Rio de Janeiro municipality with national and international fiscal support, similarly included projects focused on improving physical infrastructure and developing new social programs in favelas $[49,70]$.

Although varying in scale and institutional arrangements, successful initiatives were often state-community partnerships that originated with state recognition of the rights and legitimacy of slum-dwellers. For instance, PRIMED in Colombia, Baan Mankong, and Favela Bairro were all large, state-sponsored slum upgrading initiatives where the urban poor were recognized as having rights and requiring a range of state services $[15,47,50]$. Having a supportive state policy framework can help to avoid boutique, one-off slum upgrading projects, which may have only limited long-term impacts upon population health. Central governments can provide sustained political and fiscal support for complex upgrading projects; municipal governments have also proved important in ensuring utilities and other service providers meet the needs of slum-dwellers [6].

\subsection{Structural Conditions for Health}

Many of our selected upgrading interventions aimed to address multiple structural inequalities, with significant potential to improve residents' economic status and reduce gender inequities. In Manila, slum-dwellers receiving piped water under the Zonal Improvement Program reported a reduction in household water expenditures; the project also eliminated three to four hours per day of 
waiting time for water and as many as $72 \%$ of beneficiaries reallocated their time to income-generating activities [41]. Following Ahmedabad's Slum Networking Project (SNP), Butala et al. [32] (p. 939) found an $18 \%$ decrease in the fraction of slum-dwellers' insurance claims due to waterborne illness in an average year. The Neighborhood Upgrading and Shelter project in Indonesia improved water, sanitation, roads, and electricity for nearly three million people and resulted in avoided health care costs of $\$ 11 \mathrm{~m}$ annually [43]. During a community-led upgrading project in Huruma, Nairobi, slum-dwellers have formed micro-savings groups that build social and economic capital, and the initiative resulted in improvements in housing, infrastructure and political recognition [61].

Furthermore, after slum upgrading projects in Visakhaptnam, Indore, and Vijaywada, India, an evaluation noted that women particularly benefited from the enhanced nighttime security, improved water provision, and public lighting [31]. Similarly, an evaluation of Ahmedabad's SNP found gender-equitable benefits from improving women's access to credit and household electricity [34]. In this upgrading project, the electricity utility issued meters and monthly bills to female-headed households, providing these women with de facto tenure security since the utility and state had no interest in evicting rate-paying customers.

\subsection{Living and Working Conditions}

Evaluations typically mentioned the projects' direct influence upon neighborhood living conditions and occasionally linked these to health outcomes or determinants, such as fear and safety. For example, projects in Cali, Bogotá, and Medellín, Colombia, all found some changes in residents' attitudes towards the police and improved perceptions of safety, but did not measure cortisol, anxiety or other risk factors for mental illness [59]. Similarly, residents of favelas in Salvador, Brazil, reported a decline in fear of crime after upgrading [53]. Evaluations of Favela Real in Paraisópolis, Sao Paulo, found that improved electricity infrastructure offered residents an address and opportunity to gain state benefits that they had been previously denied [51]. Meanwhile, after upgrading Cape Town's informal settlement of Imizamo Yethu, beneficiaries felt greater community pride and social inclusion, but shack-dwellers who did not receive upgraded houses reported increased stress, stigma, and social exclusion [63]. In India, the Philippines, and Pakistan, slum-dwellers have planned, financed, and implemented sanitation initiatives with significant positive influence on environmental determinants of health $[32,41,46]$. For instance, in Karachi, community-led sanitation interventions under the Orangi Pilot Project have been linked to decreases in infant mortality and enhanced government recognition of slum-dwellers [46]. In Ahmedabad, the Mahila Housing Trust (MHT), the housing cooperative of the Self-Employed Women's Association (SEWA), led a sanitation project that reduced by $50 \%$ the likelihood of a resident reporting a waterborne illness [32].

\section{Discussion: Integrating Health Equity into Urban Slum Upgrading}

Including health and social determinants criteria into slum upgrading projects is clearly challenging. Our scan of the literature found a limited number of integrated evaluations, and some reasons might be that there are few incentives from donors and national governments for such studies, that there are methodological challenges that make impact evaluations challenging, and resources may not exist after project implementation to conduct detailed studies of often highly mobile urban populations [71]. Further, as Cameroon et al. note from a systematic review of impact evaluations between 1981 and 2014, very little impact evaluation evidence exists of interventions in urban development, including informal settlements [71]. The World Bank's Independent Evaluation Group (IEG) reports that only $17 \%$ of completed projects included an impact evaluation in their required Implementation Completion and Result Reports (ICRs) [72]. Thus, we suggest that the lack of evaluations for urban slum upgrading is a lost opportunity for improving understanding of what can work for global health. In this final section, we explore practices that might better encourage the political processes and information- gathering needed for measuring the broad health impacts of urban slum upgrading. 
Two existing practices, Health Impact Assessment (HIA) and Health in All Policies (HiAP), might help more explicitly incorporate social and environmental determinants of health into urban slum upgrading. Both HIA and HiAP aim to promote rigorous, comprehensive planning processes and to mainstream analyses of health equity throughout public policy-making. HIA seeks to systematically judge the potential (and sometimes unintended) effects of a policy, project, or other intervention upon population health as well as the distribution of those effects. Both a process and a method of analysis, HIA aims for transparent decision-making, integrating multiple health determinants, and assessing the short- and long-term health impacts upon specific groups and general population health [73]. Some local and national governments have formally institutionalized HIA as a distinct practice in public health and other agencies; other governments integrate HIA into existing health analyses and public decision-making analyses. However, to our knowledge, there is no instance where HIA has been used in slum upgrading.

HIA is also a strategy for implementing HiAP, a second integrated approach to decision-making that holds promise for slum upgrading [74]. HiAP recognizes that most public policies can influence health and health equity (either positively or negatively), but policymakers beyond the health sector may not routinely consider these consequences and thus miss opportunities to advance health equity [75]. The impetus for HiAP emerged, in part, from the WHO's Alma-Ata Declaration in 1978 and reflects numerous international calls for policy action to address the social determinants of health. The European Union and numerous governments globally have endorsed HiAP, but we have not seen it applied to either international aid or within national policies to support slum upgrading [76].

Both HIA and HiAP are rooted in relational analyses of place and population health, a framework that may help further elucidate how slum upgrading projects can be designed and evaluated for their potential health impacts [77,78]. For example, in the "relational" view of place and health, interventions aim to avoid the use of traditional, single exposure, disease or risk factor focused strategies and instead seek co-benefits of mutually reinforcing interventions. Similarly, in a relational view, a set of integrated strategies for slum upgrading would need to be implemented at multiple scales, from the national to the local, to have widespread population health impacts. As we discovered in our review, there are slum upgrading projects and policies that aim to embody the relational approach. The examples from Pakistani and Thai cities, as noted above, suggest that a relational approach to urban slum upgrading is not only possible, but can deliver tangible health gains to the urban poor.

A relational approach also demands multiple sources of data to inform project design, implementation and evaluation. For example, oral histories that capture local meanings and a "sense of place", are combined with quantitative measures of exposures and geography in a relational view of place. Again, we found that some integrated slum upgrading projects in Brazil, among others, valued resident experiences, knowledge and oral histories, along-side other forms of measurement data.

A relational approach to upgrading would also analyze the shifts, if any, in governance (rules, norms, laws and institutional procedures or practices) that often create slums and might act to stymie opportunities for the urban poor to make healthy decisions $[4,5,9]$. Thus, a relational approach would examine any changes in power between slum-dwellers and other institutions, particularly the state. The projects we reviewed rarely explored these types of governance impacts, although studies in Brazil, Colombia and Thailand did discuss changes in state-community relations. In Table 3, we detail the potential pathways between slum upgrading and key determinants of health equity. 
Table 3. Select upgrading characteristics and related health benefits.

\begin{tabular}{ll}
\hline \multicolumn{1}{c}{ Slum Upgrading Characteristic (Select) } & \multicolumn{1}{c}{ Health Influences (Examples) } \\
\hline $\begin{array}{l}\text { Community Empowerment and Political } \\
\text { Recognition via Participatory Upgrading }\end{array}$ & Trust; empowerment; control of life decisions [28] \\
\hline Right to Remain (In Situ Upgrading) & $\begin{array}{l}\text { Social connections; collective efficacy; no fear of } \\
\text { displacement [79] }\end{array}$ \\
\hline Housing Improvements and Land Tenure & $\begin{array}{l}\text { Reduced anxiety from fear of displacement; address can } \\
\text { result in social services, access to banking, etc. [80] }\end{array}$ \\
\hline Safety and Security & $\begin{array}{l}\text { Reduced gender-based violence; reduced physical } \\
\text { violence; improved mental health [81] }\end{array}$ \\
\hline Integration of Slums into Formal City & $\begin{array}{l}\text { Transportation and access to employment, education and } \\
\text { services; reduced isolation and segregation [82] }\end{array}$ \\
\hline Poverty Reduction & \begin{tabular}{l} 
Income for food, electricity and other services [8] \\
\hline Climate Change Resilience
\end{tabular} \\
\hline
\end{tabular}

\section{Conclusions}

Urban slum upgrading is a process and set of outcomes that can positively influence multiple determinants of health and potentially reduce health inequities experienced by the urban poor. The review presented here suggests that more work is needed to integrate clear social determinants criteria into slum upgrading projects' design and evaluations. When health is included in urban slum upgrading, it is often limited to a single disease, exposure or risk factor, rather than the multiple criteria for health recognized by the WHO findings on the social determinants of health. The global community's failure to recognize urban slum upgrading as an environmental health equity intervention is a lost opportunity and one that, if it continues, may hinder our ability to meet the Sustainable Development Goals.

The review presented here was limited by focusing only on published evaluations of past slum upgrading projects and policies, all of which were published in English and Spanish. Important projects with only one evaluation and those published in other languages may have been missed. We also acknowledge that slum upgrading projects and related evaluations may be intentionally narrow, in order to respond to financing and/or donor requirements. Development agencies and foundations that typically finance slum upgrading increasingly require quantifiable outputs and might measure a narrow set of health outcomes, rather than the subtler, often qualitative and harder to measure environmental and social determinants discussed here. However, the use of mixed-methods evaluations, such as in-depth interviews, focus group discussions, before-and-after spatial mapping, and longitudinal cohort surveys, could all deepen understanding of how slum upgrading can influence the multiple drivers of human health in cities. Further research can fine-tune these evaluation techniques, and slum upgrading remains an important health promotion strategy urgently requiring the attention of public health practitioners.

Author Contributions: Alice Sverdlik and Jason Corburn conceived and wrote the article; Alice Sverdlik performed the review of slum upgrading projects.

Conflicts of Interest: The authors declare no conflict of interest.

\section{References}

1. World Health Organization, Commission on Social Determinants of Health. Closing the Gap in a Generation: Health Equity through Action on the Social Determinants of Health; CSDH Final Report; WHO: Geneva, Switzerland, 2008. 
2. Unger, A.; Riley, L.W. Slum health: From understanding to action. PLoS Med. 2007, 4, e295. [CrossRef] [PubMed]

3. Harpham, T. Urban health in developing countries: What do we know and where do we go? Health Place 2009, 15, 107-116. [CrossRef] [PubMed]

4. De Snyder, V.N.; Friel, S.; Fotso, J.C.; Khadr, Z.; Meresman, S.; Monge, P.; Patil-Deshmukh, A. Social conditions and urban health inequities: Realities, challenges and opportunities to transform the urban landscape through research and action. J. Urban Health 2011, 88, 1183-1193. [CrossRef] [PubMed]

5. Abdenur, A. Global Review of Political Economy of Slum Improvement Schemes: Constraints and Policy Orientations; World Bank: Washington, DC, USA, 2009.

6. Greene, M. Main Policy and Programmatic Approaches to Slum Upgrading. Available online: http://api.ning.com/files/Vq9yIsbNU6J0hnc0vRBla0gBITdAp75AR* cUYiUPoaCEmRuHFDNLOU0ivewN7X10YkgkUVUuK7g2Zm5JutKftMQCtIbnAapA/

JointWorkProgram_LiteratureReview_FINALjune2010.pdf (accessed on 10 June 2016).

7. Field, E.; Kremer, M. Impact Evaluation for Slum Upgrading Interventions; Harvard University: Cambridge, MA, USA, 2006.

8. Turley, R.; Saith, R.; Bhan, N.; Rehfuess, E.; Carter, B. Slum upgrading strategies involving physical environment and infrastructure interventions and their effects on health and socio-economic outcomes. Cochrane Database Syst. Rev. 2013. [CrossRef]

9. WHO and UN-Habitat. Hidden Cities: Unmasking and Overcoming Health Inequities in Urban Settings; WHO: Geneva, Switzerland; UN-Habitat: Nairobi, Kenya, 2010.

10. Ezeh, A.; Oyebode, O.; Satterthwaite, D.; Chen, Y.F.; Ndugwa, R.; Sartori, J.; Mberu, B.; Melendez-Torres, G.J.; Haregu, T.; Watson, S.I.; et al. The history, geography, and sociology of slums and the health problems of the people who live in slums. Lancet 2016. [CrossRef]

11. Haines, A.; Bruce, N.; Cairncross, S.; Davies, M.; Greenland, K.; Hiscox, A.; Lindsay, S.; Satterthwaite, D.; Wilkinson, P. Promoting health and advancing development through improved housing in low-income settings. J. Urban Health 2013, 90, 810-831. [CrossRef] [PubMed]

12. Cohen, M. Urban assistance and the material world: Learning by doing at the World Bank. Environ. Urban. 2001, 3, 37-60. [CrossRef]

13. Gulyani, S.; Talukdar, D. Slum real estate: The low-quality high-price puzzle in Nairobi's slum rental market and its implications for theory and practice. World Dev. 2008, 36, 1916-1937. [CrossRef]

14. Brakarz, J.; Jaitman, L. Evaluation of Slum Upgrading Programs: Literature Review and Methodological Approaches. Available online: http://publications.iadb.org/handle/11319/6021?locale-attribute=en (accessed on 25 April 2016).

15. Boonyabancha, S. Land for housing the poor by the poor: Experiences from the Baan Mankong Nationwide Slum Upgrading Programme in Thailand. Environ. Urban. 2009, 21, 309-329. [CrossRef]

16. Riley, L.W.; Ko, A.I.; Unger, A.; Reis, M.G. Slum health: Diseases of neglected populations. BMC Int. Health Hum. Rights 2007, 7. [CrossRef] [PubMed]

17. World Health Organization. Global Report on Urban Health: Equitable Healthier Cities for Sustainable Development; World Health Organization: Geneva, Switzerland, 2016.

18. Landrigan, P.J.; Fuller, R.; Horton, R. Environmental pollution, health, and development: A lancet-global alliance on health and pollution-icahn school of medicine at Mount Sinai Commission. Lancet 2015, 386, 1429-1431. [CrossRef]

19. Bain, R.; Cronk, R.; Hossain, R.; Bonjour, S.; Onda, K.; Wright, J.; Yang, H.; Slaymaker, T.; Hunter, P.; Prüss-Ustün, A.; et al. Global assessment of exposure to fecal contamination through drinking water based on a systematic review. Trop. Med. Int. Health 2014, 19, 917-927. [CrossRef] [PubMed]

20. Corburn, J.; Hildebrand, C. Slum sanitation and the social determinants of women's health in Nairobi, Kenya. J. Environ. Public Health 2015. [CrossRef] [PubMed]

21. Unger, A. Children's health in slum settings. Arch. Dis. Child 2013, 98, 799-805. [CrossRef] [PubMed]

22. Gruebner, O.; Khan, M.M.; Lautenbach, S.; Müller, D.; Krämer, A.; Lakes, T.; Hostert, P. Mental health in the slums of Dhaka: A geoepidemiological study. BMC Public Health 2012, 12, 177. [CrossRef] [PubMed]

23. Sverdlik, A. Ill health and poverty: A literature review on health in informal settlements. Environ. Urban. 2011, 23, 123-155. [CrossRef] 
24. Parks, M.J. Urban poverty traps: Neighbourhoods and violent victimisation and off ending in Nairobi, Kenya. Urban Stud. 2014, 51, 1812-1832. [CrossRef]

25. Subbaraman, R.; O'Brien, J.; Shitole, T.; Sawant, K.; Bloom, D.E.; Patil-Deshmukh, A. Off the map: The health and social implications of being a non-notified slum in India. Environ. Urban. 2012, 24, 643-663. [CrossRef] [PubMed]

26. Joshi, R. Integrated Slum Development: Case of Pravinnagar-Guptanagar. In Poverty and Vulnerability in a Globalising Metropolis Ahmedabad; Kundu, A., Madadevia, D., Eds.; Manak Publications: Kapurthala, India, 2002; pp. 269-308.

27. Sheuya, S.A. Improving the health and lives of people living in slums. Ann. N. Y. Acad. Sci. 2008, 1136, 298-306. [CrossRef] [PubMed]

28. Rojas, E. Building Cities: Neighborhood Upgrading and Urban Quality of Life; Inter-American Development Bank: Washington, DC, USA, 2010.

29. UN Habitat. A Practical Guide to Designing, Planning, and Executing Citywide Slum Upgrading Programmes. Available online: http://uni.unhabitat.org/a-practical-guide-to-designing-planning-andexecuting-citywide-slum-upgrading-programmes / (accessed on 7 July 2016).

30. Amis, P. Rethinking UK aid in urban India: Reflections on an impact assessment study of slum improvement projects. Environ. Urban. 2001, 13, 101-113. [CrossRef]

31. Amis, P.; Kumar, S. Urban economic growth, infrastructure and poverty in India: Lessons from Visakhapatnam. Environ. Urban. 2000, 12, 185-196. [CrossRef]

32. Butala, N.; VanRooyen, M.; Patel, R. Improved Health Outcomes in Urban Slums through Infrastructure Upgrading. Soc. Sci. Med. 2010, 7, 935-940. [CrossRef] [PubMed]

33. Baruah, B. Energy services for the urban poor: NGO participation in slum electrification in India. Environ. Plann. C Politics Policy 2010, 28, 1011-1027. [CrossRef]

34. Das, A.K.; Takahashi, L.M. Evolving institutional arrangements, scaling up, and sustainability: Emerging issues in participatory slum upgrading in Ahmedabad, India. JPER 2009, 29, 213-232. [CrossRef]

35. Burra, S.; Patel, S.; Kerr, T. Community-designed, built and managed toilet blocks in Indian cities. Environ. Urban. 2003, 15, 11-32. [CrossRef]

36. Buckley, R.M.; Kallergis, A.; Deuskar, C. A Review of the Asian Coalition for Community Action Approach to Slum Upgrading; World Bank Publications: Washington, DC, USA, 2013.

37. Archer, D. Finance as the key to unlocking community potential: Savings, funds and the ACCA Programme. Environ. Urban. 2012, 24, 423-440. [CrossRef]

38. Boonyabancha, S. Baan Mankong: Going to scale with "slum" and squatter upgrading in Thailand. Environ. Urban. 2005, 17, 21-46.

39. Soegijoko, S. Managing the delivery of urban services for the poor in Indonesia: Case study of KIP in Bandung. Reg. Dev. Dialogue 1985, 6, 78-98.

40. Devas, N. Indonesia's Kampung improvement program: An evaluative case study. Ekistics 1981, 286, 19-36.

41. Aiga, H.; Umenai, T. Impact of improvement of water supply on household economy in a squatter area of Manila. Soc. Sci. Med. 2001, 55, 627-641. [CrossRef]

42. Viloria-Williams, J. Urban Community Upgrading: Lessons from the Past_Prospects for the Future; World Bank Publications: Washington, DC, USA, 2006.

43. Asian Development Bank (ADB). Project Completion Report Neighborhood Upgrading and Shelter Sector Project; Asian Development Bank: Mandaluyong, Philippines, 2012.

44. Syukri, M.; Mawardi, M.S. Sharing Knowledge on Community-Driven Development in Indonesia: An Assessment of the Neighborhood Upgrading and Shelter Sector Project. Available online: http: //www.smeru.or.id/sites/default/files/publication/cdd_eng_0.pdf (accessed on 3 January 2017).

45. Pervaiz, A.; Rahman, P.; Hasan, A. Lessons from Karachi: The Role of Demonstration, Documentation, Mapping and Relationship Building in Advocacy for Improved Urban Sanitation and Water Services; International Institute for Environment and Development (IIED): London, UK, 2008.

46. Hasan, A. Participatory Development: The Story of the Orangi Pilot Project-Research and Training Institute and the Urban Resource Centre, Karachi, Pakistan; Oxford University Press: Oxford, UK, 2010.

47. Betancur, J.J. Approaches to the Regularization of Informal Settlements: The Case of PRIMED in Medellin, Colombia. Available online: http:/ / siteresources.worldbank.org/INTURBANDEVELOPMENT/Resources / 336387-1269364699096/6892630-1269364758309/betancur.pdf (accessed on 3 July 2016). 
48. UNESCO. Programa Lntegral de Mejoraimento de Barríos Subnormales en Medellín. Available online: http:/ / unesdoc.unesco.org/images/0012/001297/129776so.pdf (accessed on 3 January 2017).

49. Soares, F.; Soares, Y. The Socio-Economic Impact of Favela-Bairro: What Do the Data Say? Inter-American Development Bank: Washington, DC, USA, 2005.

50. Project Completion Report (PCR). Rio de Janeiro Urban Upgrading Program, "Favela-Bairro"-Stage II. BR0250. 2007. Available online: http://idbdocs.iadb.org/wsdocs/getdocument.aspx?docnum=1025507 (accessed on 11 November 2016).

51. United States Agency for International Development (USAID). Innovative Approaches to Slum Electrification; USAID: Washington, DC, USA, 2004. Available online: http://pdf.usaid.gov/pdf_docs/PNADB219.pdf (accessed on 1 August 2016).

52. World Bank. Brazil Country Program Evaluation, FY2004-11: Evaluation of the World Bank Group Program; World Bank Publications: Washington, DC, USA, 2014.

53. Baker, J.L. Integrated Urban Upgrading for the Poor: The Experience of Ribeira Azul, Brazil. Available online: http:/ / dx.doi.org/10.1596/1813--9450--3861 (accessed on 3 January 2017).

54. Cities Alliance. Alagados-The Story of the Integrated Slum Upgrading in Salvador (Bahia), Brazil; Cities Alliance: Washington, DC, USA, 2008.

55. Cattaneo, M.D.; Galiani, S.; Gertler, P.J.; Martinez, S.; Titiunik, R. Housing, health, and happiness. Am. Econ. J. Econ. Policy 2009, 1, 75-105. [CrossRef]

56. Glassman, A.; Temin, M. Millions Saved: New Cases of Proven Success in Global Health; Brookings Institution Press: Washington, DC, USA, 2016.

57. Stein, A.; Vance, I. The role of housing finance in addressing the needs of the urban poor: Lessons from Central America. Environ. Urban. 2008, 20, 13-30. [CrossRef]

58. Stein, A. Participation and sustainability in social projects: The experience of the Local Development Programme (PRODEL) in Nicaragua. Environ. Urban. 2001, 13, 11-35. [CrossRef]

59. Abuelafia, E. An Evaluation of the Support for Peaceful Coexistence and Citizen Security: Bogotá and Medellín. Available online: http://idbdocs.iadb.org/wsdocs/getdocument.aspx?docnum=35572731 (accessed on 11 July 2016).

60. Giraldo Ramírez, J. La Conflicto Armado Urbano y Violencia Homicida: El Caso de Medellín; Urvio, Revista Latinoamericana de Seguridad Ciudadana: Quito, Ecuador, 2008; Volume 5.

61. Weru, J. Community federations and city upgrading: The work of Pamoja Trust and Muungano in Kenya. Environ. Urban. 2004, 16, 47-62. [CrossRef]

62. Lines, K.; Makau, J. Muungano Nguvu yetu (Unity is Strength): 20 Years of the Kenyan Federation of Slum Dwellers. Available online: http://pubs.iied.org/10807IIED/?c=urban (accessed on 3 January 2017).

63. Shortt, N.K.; Hammett, D. Housing and health in an informal settlement upgrade in Cape Town, South Africa. J. Hous. Built Environ. 2013, 28, 615-627. [CrossRef]

64. Barry, M. Boundary Systems in Informal Settlement Upgrades: Imizamo Yethu Settlement in Cape Town. Available online: https://www.researchgate.net/profile/Michael_Barry9/publication/282948235_ Boundary_systems_in_informal_settlement_upgrades_Imizamo_Yethu_settlement_in_Cape_Town/links / 56242adb08aea35f26868e30.pdf (accessed on 11 November 2016).

65. Gulyani, S.; Bassett, E.M. Retrieving the baby from the bathwater: Slum upgrading in Sub-Saharan Africa. Environ. Plan. C Politics Policy 2007, 25, 486-515. [CrossRef]

66. Cronin, V.; Guthrie, P. Alternative approaches to slum upgrading in Kibera, Nairobi. Proc. ICE Urban Des. Plan. 2011, 164, 129-139. [CrossRef]

67. Ndung'u, M. Evaluation of Slum Upgrading Programme (Kensup): Case Study of Mavoko Sustainable Neighbourhood Programme in Machakos County; University of Nairobi: Nairobi, Kenya, 2012.

68. Syagga, P.M.; Mitullah, W.; Gitau, S.K. Slum Upgrading: Lessons Learned in Nairobi. Urban Governance and Urban Poverty: Lessons from a Study of Ten Cities in the South. Available online: https:/ / unhabitat. org/downloads/docs/3642-39011-HS-C (accessed on 3 January 2017).

69. Rigon, A. Building local governance: Participation and elite capture in slum-upgrading in Kenya. Dev. Chang. 2014, 45, 257-283. [CrossRef]

70. Cities Alliance. Slum Upgrading Up Close: Experiences of Six Cities; Cities Alliance: Brussels, Belgium, 2008.

71. Cameron, D.B.; Mishra, A.; Brown, A.N. The growth of impact evaluation for international development: How much have we learned? J. Dev. Eff. 2016, 8, 1-21. [CrossRef] 
72. Independent Evaluation Group (IEG). Learning and Results in World Bank Operations. Available online: https:/ /ieg.worldbankgroup.org/Data/Evaluation/files/learning_results_eval.pdf (accessed on 3 January 2017).

73. Harris-Roxas, B.; Harris, E. Differing forms, differing purposes: A typology of health impact assessment. Environ. Impact Assess. Rev. 2013, 31, 396-403. [CrossRef]

74. Corburn, J.; Curl, S.; Arrendondo, G. Health in all urban policy: City services through the prism of Health. J. Urban Health. 2014, 91, 623-636. [CrossRef] [PubMed]

75. World Health Organization (WHO). Health in All Policies. Available online: http://www.euro.who.int/ en/health-topics/health-determinants/social-determinants/policy/entry-points-for-addressing-sociallydetermined-health-inequities/health-in-all-policies-hiap (accessed on 28 June 2016).

76. Kickbusch, I. Health in all policies: Setting the scene. Public Health Bull. 2008, 5, 3-5. [CrossRef] [PubMed]

77. Cummins, S.; Curtis, S.; Diez-Roux, A.V.; Macintyre, S. Understanding and representing "place" in health research: A relational approach. Soc. Sci. Med. 2007, 65, 1825-1838. [CrossRef] [PubMed]

78. Corburn, J. Healthy City Planning: From Neighborhood to National Health Equity; Routledge: London, UK, 2013.

79. Van Gelder, J.L. Then I'll Huff, and I'll Puff, and I'll...: A natural experiment on property titling, housing improvement and the psychology of tenure security. Int. J. Urban Reg. Res. 2013, 37, 734-749. [CrossRef]

80. Galiani, S.; Schargrodsky, E. Effects of land titling on child health. Econ. Hum. Biol. 2004, 2, $353-372$. [CrossRef] [PubMed]

81. Muggah, R. Researching the Urban Dilemma: Urbanization, Poverty and Violence. Available online: https:/ / www.idrc.ca/sites/default/files/sp/Images/Researching-the-Urban-Dilemma-Baselinestudy.pdf (accessed on 1 August 2016).

82. Bai, X.; Nath, I.; Capon, A.; Hasan, N.; Jaron, D. Health and wellbeing in the changing urban environment: Complex challenges, scientific responses, and the way forward. Curr. Opin. Environ. Sustain. 2012, 4, 465-472. [CrossRef]

83. Scovronick, N.; Lloyd, S.J.; Kovats, R.S. Climate and health in informal urban settlements. Environ. Urban. 2015, 27, 657-678. [CrossRef]

(C) 2017 by the authors. Licensee MDPI, Basel, Switzerland. This article is an open access article distributed under the terms and conditions of the Creative Commons Attribution (CC BY) license (http:/ / creativecommons.org/licenses/by/4.0/). 